\title{
Efektivitas online group CBT pada stres dan coping strategy remaja perempuan yang terdampak covid-19
}

\author{
Ayu Kartika ${ }^{1}$ dan Mita Aswanti Tjakrawiralaksana ${ }^{2}$
}

\begin{abstract}
The COVID-19 pandemic has prompted the Indonesian government to implement a distance learning system. Changes and uncertainties might deteriorate mental health, especially in female adolescents who were initially prone to experiencing stress based on their developmental stage and gender. This study aims to determine the effectiveness of stress management training with Online Group Cognitive Behavioral Therapy approaches in reducing stress and developing adaptive coping strategies. A total of 8 participants (ages 14-15) were recruited online with the purposive sampling technique. Changes in stress levels and coping strategies were tested using Friedman's ANOVA test. There was a significant reduction in stress that continued until 1-month follow-up and increased adaptive coping strategies after the intervention (post-test). Participants also reported positive changes in cognition and emotion, including increased belief about their ability to handle stress in the future. However, there was no statistically significant reduction in a maladaptive coping strategy. Additional factors, such as individual differences and interactions with the environment influenced the intervention's effectiveness.
\end{abstract}

\section{Keywords}

online group CBT, stress, coping strategy, adolescent

\section{Pendahuluan}

Sejak Desember 2019, sistem kesehatan di seluruh dunia sedang menghadapi lonjakan kasus coronavirus (2019nCoV) atau COVID-19 yang bermula dari Wuhan Cina dan telah menyebar di berbagai negara hingga lebih dari 100.000 kasus dalam waktu tiga bulan (Inchausti et al., 2020). Mulai Januari 2020, World Health Organization (2020) juga mendeklarasikan pandemic COVID-19 sebagai kondisi darurat kesehatan internasional dan hingga Mei 2020 sudah tercatat 5.701.337 kasus terkonfirmasi COVID-19 dari 216 negara. Begitu pula di Indonesia dengan kemunculan kasus pertama pada Maret 2020 dan per tanggal 30 Mei 2020 sudah tembus 25.216 kasus positif COVID-19 dengan angka kematian sebanyak 1.520 orang (Kementerian Kesehatan Republik Indonesia, 2020). Kondisi ini pun ikut mempengaruhi kebijakan pemerintah yang juga berdampak pada aktivitas seharihari masyarakat, seperti Pembatasan Sosial Berskala Besar (PSBB) pada beberapa daerah di Indonesia.

PSBB ini mewajibkan masyarakat untuk melakukan karantina secara mandiri di rumah. Tidak hanya terdampak secara ekonomi, kondisi psikologis dan kesejahteraan masyarakat dalam jangka pendek maupun panjang pun berisiko terganggu termasuk bagi remaja yang diwajibkan mengikuti pembelajaran di rumah sejak akhir Maret 2020. Penelitian sebelumnya menunjukkan sama seperti orang dewasa, pada masa pandemik remaja juga mengalami perasaan takut, menghadapi ketidakpastian, isolasi fisik dan sosial, serta merindukan pengalaman bersekolah (Jiao et al., 2020; Rubin, 2020; Wang et al., 2020). Berbagai sumber perasaan negatif yang mungkin dialami remaja selama pandemik antara lain ketakutan terinfeksi penyakit, kehilangan orang yang dicintai, harus terpisah dengan anggota keluarga yang bekerja sebagai tenaga kesehatan, frustrasi dan kejenuhan, paparan pada pemberitaan negatif di media masa, kurangnya kontak sosial dengan teman sebaya, terbatasnya ruang gerak pribadi di rumah, dan masalah finansial keluarga (Brooks et al., 2020; Jiao et al., 2020; Rubin, 2020; Wang et al., 2020).

Berdasarkan hasil studi awal yang dilakukan oleh China-EPA/UNEPSA di provinsi Shaanxi Cina pada Februari 2020, orang tua melaporkan munculnya masalah psikologis pada anak dan remaja, seperti menjadi terlalu menempel dengan orang tua, inatentif, gelisah dan mudah marah, takut menanyakan hal-hal terkait pandemik, masalah tidur termasuk mimpi buruk, rendahnya nafsu makan, dan ketidaknyamanan secara fisik (Jiao et al., 2020). Anak dan remaja juga melaporkan perasaan takut,

\footnotetext{
${ }^{1,2}$ Fakultas Psikologi Universitas Indonesia

Korespondensi:

Ayu Kartika, Fakultas Psikologi, Universitas Indonesia, Depok, 16424, Indonesia

Email: ayu.kartika82@ui.ac.id; mita.aswanti@ui.ac.id
} 
cemas, dan kelelahan yang tinggi terutama ketika mereka tinggal di zona dengan kasus positif COVID-19 yang tinggi. Tingkat stres pasca trauma pada remaja yang sedang dikarantina juga 4 kali lebih tinggi dibandingkan remaja yang tidak dikarantina (Brooks et al., 2020).

Hal yang sama juga ditemukan dari hasil survei daring oleh peneliti di bulan Maret 2020 pada 290 remaja berusia 11-19 tahun dari Jabodetabek, Pati, Semarang, Lampung, Mataram, dan Dampal Utara yang menjalani Pembelajaran Jarak Jauh selama 20-40 hari. Partisipan melaporkan perasaan jenuh, sedih, takut, cemas, kesal, tertekan, kelelahan, lebih mudah terdistraksi, dan kurang termotivasi dalam belajar dibandingkan sebelum mengikuti pembelajaran di rumah. Perasaan negatif ini utamanya muncul karena terbatasnya interaksi sosial dengan teman sebaya. Hal ini diikuti dengan munculnya pemikiran dan perasaan kurang berdaya, tidak kompeten, akan mengalami kegagalan ketika ujian, dan khawatir tertinggal dari teman lainnya dalam mengerjakan tugas-tugas yang juga dirasa terlalu banyak tanpa adanya penyesuaian metode pengajaran maupun waktu pengumpulan tugas. Muncul pula kekhawatiran akan kondisi perekonomian keluarga dan kemungkinan diri sediri ataupun keluarga terjangkit penyakit.

Berbagai situasi yang dialami remaja selama pandemik COVID-19 ini pun berisiko menimbulkan stres, yakni suatu kondisi ketika individu mempersepsikan lingkungan memberikan tuntutan yang melebihi sumber dayanya dan membahayakan kesejahteraannya (Lazarus \& Folkman, 1984). Secara umum tanpa kondisi pandemi, masa remaja berisiko mejadi onset berkembangnya gangguan sosial emosional karena dikaitkan dengan perubahan hormonal dan morfologi akibat pubertas; perubahan pola tidur; meningkatnya reaktivitas emosional yang tidak diimbangi dengan kemampuan meregulasi emosi; perubahan terkait hakikat dan pentingnya hubungan dengan teman sebaya; dan perubahan konsep diri atau identitas (Rapee et al., 2019). Meskipun demikian, penelitian sebelumnya menunjukkan remaja awal perempuan (usia 12-15 tahun) berisiko mengalami stres yang lebih tinggi dibandingkan laki-laki (Rapee et al., 2019). Secara biologis, remaja perempuan mengalami pubertas lebih cepat, sehingga turut mempengaruhi perubahan kondisi mood, bertambahnya pengalaman reaktivitas emosional, sekaligus meningkatkan kekhawatirannya akan penilaian sosial terutama terkait penampilan maupun kenaikan berat badan (Östberg et al., 2015; Rapee et al., 2019). Remaja perempuan juga dilaporkan memiliki level salivary cortisol lebih tinggi di pagi hari sebagai perwujudan dari level kecemasan yang tinggi dan rendahnya kualitas tidur (Östberg et al., 2015).

Perbedaan gender juga muncul disebabkan perbedaan jumlah atau tipe sumber stres, interpretasi terhadap stimulus pemicu stres atau reaktivitas terhadap stres, dan sumber daya atau strategi mengatasi stres (Östberg et al., 2015). Memasuki usia remaja, perempuan menaruh perhatian lebih besar pada hubungan interpersonal dan penilaian sosial sekaligus berusaha untuk menerapkan coping strategy agar bisa mempertahankan relasi tersebut (Östberg et al., 2015; Rapee et al., 2019). Masalahnya, relasi dengan teman sebaya juga bisa menjadi sumber konflik dan penolakan sosial, sehingga menjadi sumber stres interpersonal termasuk mempengaruhi keberhargaan diri remaja perempuan (Magson et al., 2021; Östberg et al., 2015). Remaja perempuan yang bertahan pada relasi destruktif yang berkepanjangan juga berisiko mengalami depresi dan kecemasan (Magson et al., 2021). Selain itu, meskipun remaja perempuan cenderung mencari dukungan sosial dari teman sebaya, namun kekhawatiran yang besar akan penilaian dan penolakan sosial juga dapat menghambatnya untuk mencari bantuan termasuk menutup diri ketika mengalami masalah personal (Yap et al., 2013). Selama pandemi ini pun semakin tebatas pula ruang gerak remaja untuk berinteraksi sosial, sehingga turut mempengaruhi berkurangnya perasaan terkoneksi secara sosial. Kondisi inilah yang berisiko menjadi sumber stres selama pandemi bagi remaja perempuan yang memiliki sensitivitas lebih besar dalam kebutuhan berelasi (Magson et al., 2021).

Hasil penelitian oleh Wilhsson et al. (2017) juga menunjukkan remaja perempuan melaporkan tekanan dan tuntutan yang lebih tinggi terkait dengan pencapaian akademik dibandingkan laki-laki. Perspesi yang kuat akan tanggung jawab personal untuk memenuhi ekspektasi lingkungan ini bisa menjadi sumber stres bagi remaja perempuan dibandingkan laki-laki. Remaja perempuan juga melaporkan kekhawatiran yang lebih besar terkait masa depan dan kesulitan untuk menikmati situasi saat ini dan terkini (present) dibandingkan remaja laki-laki. Hal ini termasuk di dalamnya kesulitan untuk menentukan prioritas, seperti memberikan waktu luang bagi diri sendiri untuk melakukan aktivitas menyenangkan sebelum ia berhasil menyelesaikan pekerjaan sekolahnya. Kondisi ini pula yang membuat remaja perempuan rentan mengalami burnout berkaitan dengan sekolah dibandingkan lakilaki. Hal yang sama ditemukan dari hasil survei bahwa remaja awal perempuan menaruh perhatian dan kekhawatiran yang besar akan kemampuan akademiknya. Remaja perempuan juga melaporkan stres akibat merasa kesulitan untuk menyesuaikan tuntutan serta perubahan metode pengajaran dari sekolah. Kendala dalam mengikuti pembelajaran daring inilah yang juga bisa menjadi faktor risiko timbulnya masalah kesehatan mental (Magson et al., 2021).

Jika tidak ditangani dengan segera, stres dapat berdampak negatif pada remaja perempuan. Penelitian sebelumnya menunjukkan stres secara umum berhubungan dengan masalah tidur, masalah konsentrasi, penurunan prestrasi akademik, rendahnya hubungan sosial, kemampuan belajar secara mandiri yang rendah, rendahnya level kesejahteraan, masalah fisik (seperti gaya hidup yang tidak sehat, rendahnya aktivitas fisik, obesitas), dan masalah psikologis lainnya seperti burnout, kecemasan, depresi, penggunaan obat-obatan, agresif (Östberg et al., 2015; Pascoe et al., 2020; Wilhsson et al., 2017). Meskipun 
tidak semua orang menampilkan gejala masalah psikologis, namun dalam jangka panjang individu yang terpapar kejadian traumatis selama pandemi COVID-19 termasuk remaja pun beresiko menampilkan simtom hipokondriasis, kecemasan, insomnia, stres akut termasuk kemungkinan post-traumatic stress disorder, depresi, dan complex grieving setelah pandemi (Duan \& Zhu, 2020).

Berbagai dampak negatif dari stres ini juga dapat diminimalisir bergantung pada tindakan individu dalam merespon situasi stres atau disebut coping (Allen \& Leary, 2010). Coping ini tidak hanya dilakukan sebagai upaya untuk memperbaiki atau menyelesaikan masalah, tetapi juga membantu individu mengubah persepsinya dan mentolerir kondisi negatif yang dialami (Sarafino \& Smith, 2011). Berdasarkan fungsinya, Lazarus \& Folkman (1980) membagi coping strategy menjadi dua, yakni yang berfokus pada tindakan nyata untuk mengubah atau mengatur hubungan individu dengan lingkungan yang menjadi sumber stres guna memecahkan masalah (problem-focused coping) dan usaha untuk mengelola emosi negatif guna mengurangi tekanan emosional yang berkaitan dengan sumber stres (emotion-focused coping).

Lebih lanjut, beberapa penelitian mengelompokkan jenis coping berdasarkan kegunaannya untuk mengelola masalah secara sehat (adaptive coping) dibandingkan dengan yang tidak sehat (maladaptive coping) (Cooper et al., 2008; Lopez, 2014; Powers et al., 2020). Mengatasi masalah secara aktif (active coping), merencanakan penyelesaian masalah (planning), mencari dukungan emosional (use of emotional support), mencari dukungan instrumental (use of instrumental support), melihat hal positif dari suatu situasi (positive reframing), penerimaan (acceptance), meningkatkan partisipasi keagamaan (religion), dan menggunakan humor masuk ke dalam kelompok adaptive coping. Di lain sisi, menyangkal (denial), melampiaskan emosi tanpa berpikir lebih dahulu (venting), menggunakan obat-obatan terlarang (substance use), menghentikan upaya untuk mengatasi masalah (behavioral disengagement), mendistraksi diri (self-distraction), dan menyalahkan diri sendiri (self-blame) sebagai maladaptive coping.

Hasil survei awal oleh peneliti pun menunjukkan bahwa remaja perempuan menggunakan strategi yang berbeda-beda dalam mengatasi stres selama kegiatan belajar di rumah pada masa pandemic COVID-19, seperti istirahat, melakukan aktivitas yang disukai, distraksi, berpikir positif, berdoa, dan meminta bantuan orang terdekat. Umumnya mereka menggunakan 1 hingga 3 coping strategies. Namun demikian, tidak sedikit pula dari mereka yang menghindari tugas-tugas, bertindak pasif ketika menghadapi stres, memendam perasaannya, dan melukai diri sendiri. Oleh karena itu, memperkaya coping strategy yang sehat diharapkan dapat membantu remaja perempuan mengatasi stres sehari-hari dan meminimalisir dampak dari stres yang dirasakan(Raheel, 2014; Rapee et al., 2019). Hal ini juga ditujukan untuk mengurasi kemungkinan remaja perempuan menerapkan coping strategy yang cenderung tidak menyelesaikan masalah (seperti menangis, ruminative style, supression, makan berlebihan, bereaksi agresif secara verbal, menarik diri) sekaligus mencegah berkembangnya masalah internalizing maupun risiko bunuh diri di kemudian hari (Raheel, 2014; Rapee et al., 2019; Wilhsson et al., 2017).

Salah satu bentuk intervensi managemen stres yang terbukti dapat menurunkan simtom stres maupun mengembangkan coping strategies yang sehat pada remaja adalah pendekatan cognitive behavioral therapy (CBT) (De Anda, 1998; Hofmann et al., 2012; Pretzer \& Beck, 2007; Keypour et al., 2011; Yahav \& Cohen, 2008). Pendekatan CBT ini akan membantu individu memodifikasi kognisi maladaptif yang menyebabkan bertahannya distres emosional dan masalah perilaku (Pretzer \& Beck, 2007). Intervensi ini pun termasuk di dalamnya meningkatkan kesadaran terkait stres, mengajarkan teknik relaksasi, restrukturisasi kognitif, penyelesaian masalah, dan manajemen waktu (Pretzer \& Beck, 2007; Keypour et al., 2011). Oleh karenanya, diharapkan intervensi ini dapat membantu remaja perempuan mampu menyadari dan mengubah disfungi kognitifnya selama mengahadapi stres sehari-hari semasa pandemic COVID-19 (seperti pemikiran "aku tidak berdaya", "aku tidak mampu", "aku akan gagal", "aku tertinggal dibandingkan teman yang lainnya", "kondisi ini tidak akan berakhir", "aku dan keluargaku akan sakit") sekaligus diajarkan teknik mengelola stres lain yang adaptif, seperti teknik relaksasi, penyelesaian masalah, dan manajemen waktu.

Lebih lanjut, penerapan pendekatan CBT di dalam kelompok juga dapat menjangkau jumlah partisipan lebih banyak tetapi juga memungkinkan remaja untuk saling mendapatkan pengetahuan, pengalaman, maupun sudut pandang baru dari partisipan lain dalam menghadapi suatu masalah, mengamati dan meniru pemikiran maupun perilaku positif partisipan lainnya, sekaligus mendapatkan penguatan sosial di dalam kelompok (De Anda, 1998; Lazarus \& Folkman, 1984; Pretzer \& Beck, 2007). Selain itu, pelaksanaan pelatihan secara daring diharapkan dapat memperkaya temuan sebelumnya terkait efektivitas intervensi dengan pendekatan CBT dalam menurunkan simtom stres dan mengembangkan coping strategy yang adaptif, menjangkau partisipan dari sekolah yang beragam, sekaligus mencegah interaksi sosial secara langsung yang dapat meningkatkan risiko penyebaran COVID-19 (Inchausti et al., 2020).

Berdasarkan paparan di atas, peneliti tertarik untuk mengetahui pengaruh pemberian pelatihan manajemen stres berbasis Online Group Cognitive Therapy dalam mengurangi gejala stres remaja perempuan usia 12-15 tahun yang menjalani Pendidikan Jarak Jauh (PJJ) selama pandemi COVID-19. Pelatihan ini juga diharapkan dapat meningkatkan keterampilan remaja perempuan menggunakan teknik coping yang lebih adaptif ketika menghadapi stres. Selain itu, hasil penelitian ini diharapkan dapat memberikan masukan bagi pihak lainnya, seperti orang tua, guru, maupun konselor sekolah yang lebih 
banyak terlibat dalam keseharian remaja berkaitan dengan pentingnya pemberian bantuan psikologis termasuk pelatihan yang mengembangkan kemampuan self-help guna meningkatkan kesehatan mental remaja, sehingga bisa membantunya menjalani fungsi sehari-harinya secara lebih optimal.

\section{Metode}

Metode penelitian adalah kuasi eksperimen untuk mengetahui pengaruh pemberian pelatihan manajemen stres dengan pendekatan Online Group Cognitive Behavior Therapy terhadap penurunan stres dan peningkatan coping strategy yang lebih adaptif pada remaja perempuan. Desain penelitian yang digunakan adalah one group pretest-posttest design with follow-up. Perubahan perilaku diukur dengan membandingkan skor stres dan coping strategy sebelum (O1), segera setelah pelatihan $(\mathrm{O} 2)$, dan follow-up 1 bulan setelah pelatihan $(\mathrm{O} 3)$.

Teknik pengambilan sampel dilakukan dengan purposive sampling. Kriteria partisipan adalah: 1) Siswa SMP perempuan berusia 12-15 tahun; 2) Telah menjalani PJJ minimal selama 1 bulan, 3) memiliki skor stres dalam kategori sedang atau tinggi dilihat dari hasil pengukuran Perceived Stress Scale (PSS), 4) Bersedia mengikuti rangkaian intervensi secara daring hingga selesai yang dibuktikan dengan pengisian informed consent oleh partisipan dan orang tua. Dari 38 partisipan yang mendaftarkan diri secara daring, terdapat 11 partisipan memenuhi kriteria partisipan. Akan tetapi, hanya 8 partisipan remaja perempuan berusia 14-15 tahun yang bertahan hingga akhir penelitian, sedangkan 3 partisipan lainnya mengundurkan diri karena sakit dan keterbatasan perangkat untuk mengikuti pelatihan secara daring. Semua partisipan tinggal di wilayah Jabodetabek.

Peneliti menggunakan dua alat ukur untuk mengukur efektivitas intervensi. Pengukuran tingkat stres dilakukan menggunakan alat ukur Perceived Stress Scale (PSS) (Cohen et al., 1983) dan telah diadaptasi ke bahasa Indonesia (Bitty et al., 2019). PSS terdiri dari 10 aitem yang mengukur sejauh mana situasi dalam kehidupan sehari-hari dianggap sebagai stres selama sebulan terakhir. Partisipan diminta untuk memberi respon terhadap pilihan jawaban skala likert 0 hingga 4 yang mewakili pernah, hampir tidak pernah (1-2 kali), kadang-kadang (3-4 kali), hampir sering (5-6 kali), dan sangat sering (lebih dari 6 kali). Tingkatan stres diketahui dengan menjumlahkan skor seluruh aitem yang nantinya dapat dikategorikan menjadi tiga level stres, yakni rendah (skor 0-13), sedang (skor 14-26), dan tinggi (27-40). Hasil uji reliabilitas oleh peneliti pada saat uji coba kepada 155 remaja didapatkan $\alpha=0.73$ yang berarti PSS menunjukkan konsistensi internal yang baik. Dari hasil uji convergent validity juga didapatkan bahwa PSS berhubungan positif dengan maladaptive coping strategy.
Coping strategy diukur dengan Brief COPE (Carver, 1997) yang sudah diadaptasi ke dalam bahasa Indonesia (Turangga, 2016) serta telah terbukti valid dan reliabel dengan koefisien validitas setiap aitem di atas 0.2 dan koefisien reliabilitas keseluruhan aitem 0.85 . Brief COPE terdiri dari 28 aitem dengan 14 sub skala dengan masing-masing 2 aitem. Carver (1997) menambahkan bahwa pengukuran BRIEF COPE dapat dikelompokkan berdasarkan tujuan penelitian. Sama seperti penelitian sebelumnya (Cooper et al., 2008; Powers et al., 2020). Penelitian ini mengelompokkan mengatasi masalah secara aktif (active coping), merencanakan penyelesaian masalah (planning), mencari dukungan emosional (use of emotional support), mencari dukungan instrumental (use of instrumental support), melihat hal positif dari suatu situasi (positive reframing), penerimaan (acceptance), meningkatkan partisipasi keagamaan (religion), dan menggunakan humor (humor) sebagai kelompok adaptive coping. Sedangkan menyangkal (denial), melampiaskan emosi tanpa berpikir lebih dahulu (venting), menggunakan obat-obatan terlarang (substance use), menghentikan upaya untuk mengatasi masalah (behavioral disengagement), mendistraksi diri (self-distraction), dan menyalahkan diri sendiri (selfblame) masuk ke dalam maladaptive coping. Partisipan diminta untuk melaporkan seberapa sering ia menerapkan coping strategy dari 1 (belum pernah) hingga 4 (sangat sering). Semakin tinggi skor menunjukkan bahwa individu semakin banyak menampilkan strategi coping (Carver, 1997). Hasil uji reliabilitas oleh peneliti pada saat uji coba menunjukkan BRIEF COPE reliabel dengan koefisien reliabilitas keseluruhan aitem sebesar 0.76 , adaptive coping sebesar 0.721, dan maladaptive coping sebesar 0.68.

Setelah intervensi, peneliti juga melakukan wawancara tidak terstruktur kepada partisipan secara individual melalui telepon maupun di dalam sesi kelompok untuk memperoleh data pendukung terkait perubahan pikiran, perasaan, dan perilaku setelah mengikuti pelatihan; perubahan keyakinan akan kemampuan diri dalam mengatasi stres di kemudian hari; manfaat pelatihan; serta kendala yang dihadapi. Selain itu, setiap selesai sesi, peneliti menanyakan tentang perubahan kondisi emosi, hal baru yang didapat setelah sesi dan hal yang bisa dipraktikkan dalam kehidupan sehari-hari. Asisten peneliti juga membantu mengobservasi keterlibatan partisipan selama mengikuti pelatihan (seperti rentang perhatian, keaktifan dalam memberikan pendapat, bertanya, menanggapi pendapat partisipan lain, atau mengikuti sesi role play, pemahaman terhadap instruksi, dan kondisi emosi).

Secara umum pelaksanaan intervensi ini akan dibagi ke dalam 4 tahap utama, yaitu:

Pre-Test, yaitu pengambilan data sebelum sesi intervensi yang diberikan bersamaan dengan proses screening partisipan. Pre-test dan screening dilakukan dengan menyebarkan formulir daring yang berisikan kuesioner Perceived Stress Scale (PSS) dan Brief COPE. Partisipan yang memenuhi kriteria mengisi data diri dan lembar persetujuan yang juga ditanda-tangani oleh orang tua. 
Pelaksanaan Intervensi, yaitu pelatihan manajemen stres melalui aplikasi video conferencing yang terdiri dari 8 pertemuan selama kurang lebih 1 bulan dengan masingmasing sesi berdurasi 60-90 menit. Modul intervensi diadaptasi dari modul Stress Management for Adolescent: A Cognitive Behavioral Program (De Anda, 2002) dan Stress Management Programme for Secondary School Students (McNamara, 2004). Berikut ini merupakan kegiatan dalam setiap pertemuan:

1. Perkenalan dan penjelasan tentang pelaksanaan intervensi

2. Berkenalan dengan stres

3. Cognitive Skills: Berkenalan dengan pikiran

4. Cognitive Skills: Trik mengelola pikiran dengan Body Scanning dan Positive Self-Talk

5. Affect Skills: Trik mengelola afektif dengan belajar relaksasi

6. Behavior Skills: Trik pemecahan masalah

7. Behavior Skills: Trik manajemen waktu

8. Review Kelas, berbagi pengalaman, dan Post-Test

Kegiatan di dalam sesi diisi dengan penyampaian materi oleh peneliti, menonton video, diskusi dalam forum maupun kelompok kecil, peragaan atau praktik langsung, dan pengerjaan lembar kerja oleh masing-masing partisipan. Pada setiap selesai sesi, partisipan melakukan debrief dalam bentuk diskusi untuk mengevaluasi manfaat dan jalannya kegiatan sekaligus memonitor perkembangan kemampuan partisipan dalam mengelola stres. Selain itu, partisipan diberikan pekerjaan rumah untuk bisa mengulang materi yang diberikan sekaligus sebagai bentuk latihan mempraktikan keterampilan coping yang sudah dipelajari. Pekerjaan rumah ini akan dibahas bersama di awal sesi sebelum materi dimulai. Partisipan juga tergabung dalam group messenger sebagai media untuk mengakses materi pelatihan maupun berkomunikasi dan berdiskusi di antara sesama partisipan serta peneliti.

Post-Test, yaitu pengukuran data kembali terkait tingkat stres dan strategi coping setelah mengikuti intervensi bersamaan dengan debriefing secara berkelompok. Partisipan juga diwawancarai secara individual melalui telepon untuk mengetahui pengalaman selama mengikuti intervensi sebagai bentuk evaluasi pikiran dan perasaan partisipan setelah mengikuti kegiatan sekaligus mengevaluasi kegiatan secara umum. Selain itu, semua partisipan yang mengikuti kegiatan hingga akhir juga mendapatkan reward berupa pulsa yang baru diberitahukan dan dibagikan setelah penelitian.

Follow-Up, yaitu pengambilan data dan diskusi mengenai pengalaman partisipan dalam menggunakan berbagai strategi coping serta kondisi stres yang dialami partisipan pada 1 bulan setelah pelaksanaan intervensi dalam sesi kelompok.

Analisis data dilakukan dengan membandingkan skor stres dan coping strategy sebelum, sesudah, dan 1 bulan setelah pelatihan manajemen stres diberikan menggunakan metode statistik uji non-parametrik Repeated Measures
ANOVA dengan Friedman's ANOVA test. Data kualitatif yang diperoleh dari hasil wawancara tidak terstruktur juga diolah dengan menggunakan inductive analysis.

\section{Hasil}

Dari Gambar 1 tampak ada penurunan rata-rata skor stres dari sebelum, segera setelah pelatihan, dan 1 bulan berikutnya. Berdasarkan pengujian Friedman's ANOVA untuk mengetahui penurunan stres pada saat pre-test, posttest, dan follow-up diperoleh $X^{2}(2)=6,69, p=0,035$. Hal ini menunjukkan adanya penurunan stres secara signifikan hingga sebulan setelah intervensi diberikan. Lebih lanjut, pengujian pairwised comparison dengan adjusted p-values menunjukkan penurunan stres paling besar tampak pada perbandingan pengukuran pre-test dan follow-up.

Jika dilihat pada Gambar 2 terdapat peningkatan skor rata-rata adaptive coping strategy pada saat post-test. Hasil analisis menunjukkan adanya perubahan penggunaan adaptive coping strategy yang signifikan dari saat pre-test, post-test, dan follow up, $X^{2}(2)=6.25, p=0.04$. Lebih lanjut, hasil pairwise comparison menunjukkan bahwa terdapat peningkatan penggunaan adaptive coping yang signifikan pada saat pre-test dan post-test $(p=0.037)$. Namun demikian, tampak perubahan adaptive coping yang tidak signifikan pada perbandingan pre-test dan followup $(p=0.634)$ maupun post-test dan follow-up ( $p=$ $0.634)$. Selain itu, tampak adanya penurunan rata-rata skor maladaptive coping strategi pada Gambar 2. Akan tetapi, hasil analisis menunjukkan tidak adanya perubahan skor maladaptive coping yang signifikan pada saat pre-test, post-test, dan follow-up, $X^{2}(2)=2.77, p=0.25$. Hal ini berarti intervensi manajemen stres berbasis online group $C B T$ kurang efektif mengurangi penggunaan maladaptive coping.

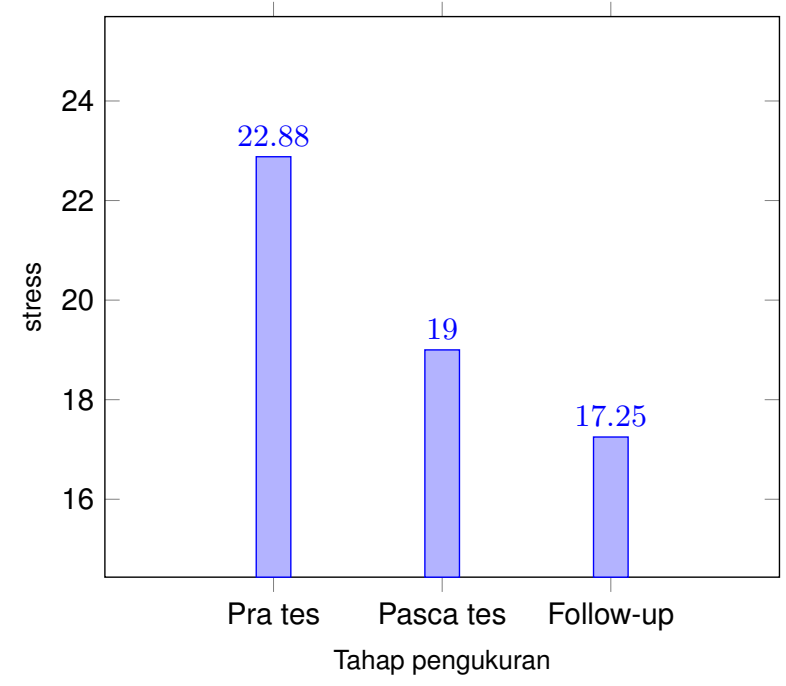

Gambar 1. Rata-rata skor stres berdasarkan waktu pengukuran 


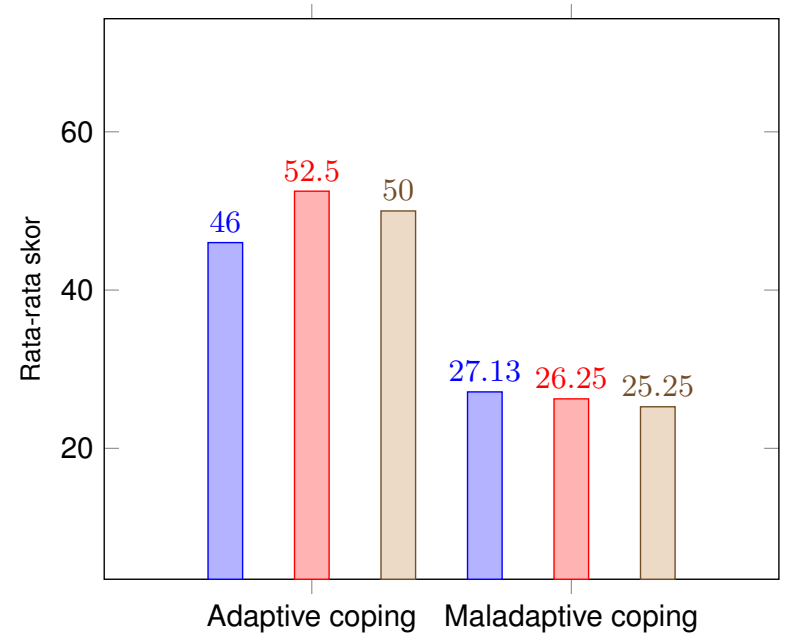

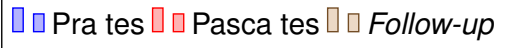

Gambar 2. Rata-rata skor adaptive coping dan maladaptive coping

Pengolahan hasil wawancara dengan inductive analysis juga dilakukan untuk mendapat data pendukung terkait dinamika perubahan pikiran, perasaan, perilaku masingmasing partisipan pada saat pre-test, post-test, dan followup. Berikut ini merupakan salah satu kutipan wawancara terkait sumber stres yang dialami partisipa selama kegiatan belajar di rumah akibat pandemi:

"Dulu ada tugas banyak aku fine fine aja. Kalau kelas online ini tugasnya makin banyak lagi.. Aku ngerasa cepek tapi nggak enak hati kalau belum ngumpulin. Apa ya kayak nggak tenang kalau belum selesai... Aku perfeksionis apa kayak semua harus sempurna, harus terstruktur. Aku takut nggak bisa sesuai ekspektasi orang lain, Tapi suka overload juga pas ada yang nggak sesuai target... Udah gitu nggak bisa ketemu temen lagi nggak bisa kerjain bareng" (LL, 14 tahun 8 bulan).

Hal yang sama disampaikan partisipan lainnya bahwa selama masa PSBB dan kegiatan belajar di rumah sumber stres utama mereka adalah akademik (seperti perasaan tidak mampu memahami materi pelajaran, kesulitan mengatur waktu mengerjakan tugas yang banyak, tidak ada penyesuaian metode pengajaran). Partisipan juga mengeluhkan masalah dalam pertemanan, seperti yang dikatakan SA (14 tahun 7 bulan) "Aku takut udah lama nggak ngobrol mereka jadi udah bosen sama aku”, Ada pula partisipan yang mengeluhkan sumber stres terkait kondisi keluarga dan tuntutan orang tua, seperti ML (14 tahun 7 bulan) yang mengatakan "Jadi bosen banget di rumah. Tersiksa banget banyak aturan... Sepele banget sebenarnya tapi tiap kali ibu ngomong "Kamu tuh anak pertama loh" tiap kali adikku yang belajar di rumah nggak bisa diatur aku jadi ngerasa gagal semuanya”. Tampak pula kekhawatiran partisipan berkaitan dengan hal yang terjadi di masa depan, seperti terjangkit penyakit dan tidak mendapatkan sekolah atau cita-cita yang diharapkan. Hal ini misalnya sesuai yang dikatakan oleh AH (15 tahun) "Aku suka tiba-tiba overthinking aja gitu nggak tau tibatiba khawatir gimana ya nanti bisa nggak ya jadi dokter terus sering tiba-tiba pengen nangis".

Setelah mengikuti pelatihan, dari segi kognitif, partisipan melaporkan adanya perubahan pikiran yang lebih positif, seperti merasa mampu mengelola emosinya ketika menghadapi stres, meyakini kelebihan dan kemampuan diri, mau mencoba kembali dan tidak menyalahkan diri sendiri ketika menghadapi suatu kegagalan, serta merasa lebih berharga, dicintai, dan diterima oleh orang lain terutama teman sebaya. Hal ini contohnya diungkapkan oleh SA, 14 tahun 7 bulan:

"Sebelumnya males banget ngerjain tugas. Temenku bisa banget ngerjain nyontek dapet 90. Nggak guna ngerjain tugas, bikin capek sendiri aja. Tapi setelahnya aku bisa mikir bukan aku doang yang banyak tugas. Bismillah, ini penentu masa depan kamu. Ayo nggak papa pelan pelan aja ngerjain tugasnya."

Dari skala 1-10, keyakinan partisipan untuk dapat mengatasi situasi stres di masa mendatang pun meningkat dari rata-rata 4,75 ketika pre-test menjadi 7,75 pada saat post-test.

Terdapat dua partisipan yang menyampaikan merasa membutuhkan waktu dan usaha yang lebih untuk mencintai dirinya sendiri dan mengelola emosi negatifnya. Hal ini disebabkan terkadang ingatan negatif tentang hubungannya dengan orang tua sebelum pandemi juga sering kali ikut terbangkitkan ketika dihadapkan pada tuntutan maupun konflik dengan orang tua selama isolasi di rumah. Akan tetapi, keduanya juga melaporkan keyakinan yang lebih tinggi akan kemampuannya untuk menghadapi stres di kemudian hari dibandingkan sebelum intervensi. Dari segi afektif, semua partisipan juga melaporkan perasaan yang lebih tenang nyaman, lega, dan senang karena merasa lebih mampu mengatasi tekanan baik setiap selesai sesi maupun setelah intervensi keseluruhan.

Dari segi perilaku, partisipan melaporkan mulai menerapkan strategi yang lebih adaptif ketika menghadapi situasi stres sehari-hari, seperti active coping, planning, positive reframing, using instrumental support, using emotional support, religion, dan acceptance. Partisipan juga melaporkan paling sering menerapkan strategi relaksasi untuk mengurangi emosi negatif yang intens (seperti deep breathing, butterfly hug, membayangkan safe place, dan relaksasi progresif). Selain itu,ada empat partisipan yang memanfaatkan buku harian sebagai media mengekspresikan diri.

Setelah mengikuti intervensi, terdapat pula satu partisipan yang melaporkan mulai dapat mengatasi ide bunuh diri yang muncul sebelum pelaksanaan intervensi dengan cara 
menerapkan teknik relaksasi. Satu partisipan lainnya juga melaporkan tidak munculnya kembali tindakan menyakiti diri dan ide bunuh diri ketika ia menghadapi stres setelah mengikuti pelatihan. Meskipun demikian, rata-rata partisipan juga menyatakan sering menggunakan self-distraction terutama ketika mereka mulai merasa kelelahan dan kesulitan untuk menghadapi masalah secara langsung.

Partisipan melaporkan sejumlah keuntungan ketika mengikuti intervensi secara berkelompok melalui daring, seperti yang dikatakan SA (14 tahun, 7 bulan) "Aku ngeliat kayak meskipun aku lebay tapi seenggaknya ada juga kok yang lain. Aku nggak sendirian. Mereka juga ngalamin stuck kayak aku...”. Meskipun pada awalnya rata-rata partisipan merasa kurang nyaman untuk membuka pengalamannya kepada partisipan lain yang baru dikenal dan memiliki kekhawatiran akan penilaian yang cenderung negatif dari kelompok (seperti dianggap berbeda, berlebihan, tidak "normal", ataupun salah ketika memberikan pendapat yang berbeda termasuk ditolak). Namun demikian, setelah pertemuan ketiga, semua partisipan melaporkan perasaan yang lebih nyaman untuk membuka diri. Pengalaman yang disampaikan oleh partisipan lain membuat partisipan merasa tidak sendirian menghadapi situasi sulit selama pandemi sekaligus mendapatkan sudut pandang baru tentang strategi yang bisa digunakan ketika menghadapi tekanan serta hal positif yang bisa dipelajari dari situasi ini. Selain itu, satu partisipan melaporkan pengalaman merasa diterima di dalam kelompok ikut mendorongnya untuk lebih membuka diri ketika menjalin relasi baru di luar kelompok setelah sebelumnya lebih sering mengalami penolakan dari teman sebaya.

Pada saat follow-up, stres yang bersumber dari akademik dan keluarga terutama tuntutan serta konflik dengan orang tua dilaporkan masih dialami partisipan. Telebih 6 dari 8 partisipan masuk ke jenjang SMA, sehingga merasa memerlukan lebih banyak usaha dan waktu untuk bisa beradaptasi di lingkungan baru. Dengan paparan sumber stres yang dirasa lebih banyak dibandingkan ketika periode intervensi, dua partisipan juga melaporkan stres yang lebih tinggi, sedangkan dua lainnya menyampaikan tidak adanya perubahan stres. Namun demikian, secara umum partisipan melaporkan perasaan lebih lega dan nyaman ketika berhasil menerapkan beberapa coping strategy yang diajarkan pada saat intervensi.

Umumnya partisipan melaporkan berusaha untuk tetap menerapkan sejumlah coping strategy yang adaptif terutama relaksasi, positive reframing, instrumental dan emotional support, religion, dan expressive writing. Meskipun demikian, semua partisipan masih sering melakukan self-distraction untuk memberi jarak dengan situasi menekan dan merasa lebih nyaman. Empat partisipan juga melaporkan terkadang masih menyalahkan diri, menyangkal kejadian, dan terlintas pikiran ingin menyerah ketika merasa kurang mampu mengatasi situasi menekan terutama berkaitan dengan pemenuhan ekspektasi orang tua. Meskipun demikian, semua partisipan juga melaporkan adanya keinginan untuk melanjutkan dan menambah penggunaan adaptive coping strategy lainnya di kemudian hari. Rata-rata keyakinan partisipan untuk bisa mengatasi situasi menekan di masa mendatang tergolong tinggi dan meningkat dibanding pada post-test yakni 8.25 dari skala 10 .

\section{Pembahasan}

Secara umum, pelatihan manajemen stres dengan pendekatan Online Group CBT bagi remaja perempuan usia 12-15 tahun yang terdampak pandemi COVID-19 dapat secara efektif menurunkan stres dan meningkatkan penggunaan adaptive coping strategy. Hal ini sejalan dengan pernyataan dan hasil temuan sebelumnya (De Anda, 1998; Chinaveh et al., 2013; Hofmann et al., 2012; Santos-Ruiz et al., 2017; Yahav \& Cohen, 2008). Efektivitas intervensi ini dapat dilihat dari adanya penurunan skor PSS pada sebagian besar partisipan, yakni 6 dari 8 partisipan segera setelah diberikan intervensi. Pada BRIEF-COPE, secara umum terlihat pula peningkatan skor dalam adaptive coping sekaligus penurunan skor maladaptive coping. Hal ini menandakan sebagian besar partisipan menggunakan strategi coping stress yang lebih efektif dibandingkan sebelum intervensi.

Sama halnya dengan penelitian sebelumnya seluruh partisipan juga melaporkan adanya penilaian yang lebih positif terkait dirinya secara umum maupun kemampuannya untuk mengatasi situasi yang menekan selama PJJ, seperti merasa lebih berdaya, berharga, diterima, dan dicintai. Partisipan juga mulai lebih menghargai proses yang dijalani ketika menghadapi berbagai situasi yang memicu stres termasuk mentolerir kesalahan, kegagalan, maupun waktu yang lebih banyak dibandingkan dengan orang lain untuk mengatasi masalahnya (De Anda, 1998; Hofmann et al., 2012; Santos-Ruiz et al., 2017). Sejalan dengan penelitian sebelumnya Pretzer \& Beck (2007) juga menyebutkan bahwa pendekatan CBT tidak hanya membantu individu mengidentifikasi pikiran yang terdistorsi setiap kali menghadapi situasi menekan, tetapi juga memfasilitasi perubahan cara individu dalam memproses informasi termasuk memahami dan memaknai situasi yang dihadapi menjadi lebih positif dengan memberikan bukti - bukti. Setelah mengikuti intervensi, keyakinan semua peserta akan kemampuannya untuk bisa mengatasi stres di kemudian hari dengan menerapkan berbagai teknik yang sudah dipelajari pun bertambah. Hal ini didukung penelitian sebelumnya bahwa dampak pelatihan manajemen stres dengan pendekatan kognitif bukan hanya mereduksi simtom stres, dan kecemasan, tetapi juga meningkatkan self-efficacy (Hains \& Szyjakowski, 1990). Meskipun demikian, penelitian ini tidak menggunakan alat ukur yang terstandarisasi, melainkan berdasarkan data kualitatif dan skala yang dibuat oleh peneliti, sehingga penelitian lanjutan diperlukan untuk mengukur perubahan self-efficacy. 
Selain positive reframing, partisipan juga melaporkan teknik relakasai sebagai coping strategy yang paling sering digunakan dan dirasa efektif untuk membantunya merasa lebih nyaman dan lega terutama ketika memiliki waktu terbatas untuk istirahat dan perlu kembali mengerjakan tugas-tugas yang menjadi salah satu sumber stres mereka. Pernyataan partisipan ini sejalan dengan penelitian sebelumnya bahwa teknik relaksasi juga dilatihkan dalam pendekatan kognitif untuk membantu individu menurunkan ketegangan fisik (Inchausti et al., 2020; Yahav \& Cohen, 2008). Selain itu, tampak peningkatan skor active coping dan planning ketika post-test maupun followup yang menandakan bahwa seperti penelitian sebelumnya, intervensi dengan pendekatan kognitif juga memperluas coping strategy individu dengan memberikannya keahlian untuk mengatasi masalah secara aktif (Chinaveh et al., 2013).

Setelah intervensi, untuk dapat mengekspresikan diri termasuk menyalurkan pikiran dan perasaannya ketika menghadapi situasi menekan, 4 (50\%) partisipan juga melaporkan melanjutkan kegiatan menulis di buku harian sebagai salah satu teknik mengelola afek. Menurut Lepore et al. (2002), dalam proses expressive writing individu mencoba mengarahkan perhatiannya untuk mengenali sumber stres yang biasanya dihindari, bagaimana respon emosi, pikiran, fisiologis, dan perilaku terhadapnya sekaligus mengenali aspek positif dari kondisi stres. Hal ini akan memfasilitasi perubahan asosiasi negatif antara stimulus stres dan respon yang dipaparkan secara berulang, sehingga bisa menurunkan respon tidak adaptif ketika kembali menghadapi stimulus dan membantu merestruktursiasi distorsi kognitif. Sama halnya dengan partisipan yang melaporkan munculnya perasaan lebih lega dan nyaman ketika bisa menjabarkan hal yang membuatnya stres tanpa khawatir akan penilaian orang lain. Kegiatan menulis juga membuat partisipan dapat menemukan alternatif solusi dan sudut pandang yang lebih positif terkait masalah.

Penelitian ini juga menunjukkan pemberian intervensi Online Group CBT tidak dapat secara signifikan menurunkan penggunaan maladaptive coping meskipun tampak penurunan skor rata-rata pada saat post-test maupun follow-up. Secara spesifik, tampak peningkatan penggunaan self-distraction ketika partisipan kesulitan menangani situasi menekan yang tidak dapat dihindari berkaitan dengan tugas-tugas sekolah tanpa adanya penyesuaian metode pengajaran dan kejenuhan berada di rumah selama PJJ. Berdasarkan penelitian sebelumnya, penggunaan selfdistraction juga dapat masuk ke dalam kategori coping strategy yang adaptif dan efektif bergantung pada situasinya terutama ketika individu menghadapi situasi yang sulit diubah ataupun dihindari (Allen \& Leary, 2010; Powers et al., 2020). Dalam hal ini distraksi masuk ke dalam acomodative atau secondary control coping tactic yang melibatkan usaha untuk mengubah tujuan individu agar lebih bisa menerima kegagalan, ataupun kondisi tidak menyenangkan (Allen \& Leary, 2010). Selain itu, meskipun distraksi melibatkan usaha untuk menjauh dari sumber stres, namun distraksi mengalihkan atensi individu kepada target yang positif (seperti kegiatan membaca dan mendengarkan musik) (Allen \& Leary, 2010). Maka dari itu, pengkategorisasian self-distraction sebagai bagian maladaptive coping strategy dalam penelitian ini perlu diteliti lebih lanjut dengan mempertimbangkan fungsi dan hubungannya dengan coping strategy lainnya dalam mengurangi stres remaja perempuan ketika menghadapi situasi PJJ akibat COVID-19 yang tidak dapat dihindari dan diprediksi kapan waktu berakhirnya.

Terdapat pula faktor perbedaan individual yang diprediksi turut mempengaruhi dinamika perubahan skor stres dan penerapan coping strategy pada masingmasing partisipan. Lazarus (1990) berpendapat proses terjadinya stres bersifat transaksional antara faktor individual (seperti tujuan, motivasi, self-efficacy, selfesteem) dengan karakteristik lingkungan (seperti tuntutan, ancaman, sumber daya), sehingga stres dapat terus berubah bergantung pada penilaian masing-masing individu dan interaksinya dengan lingkungan. Dalam penelitian ini, meskipun semua partisipan menghadapi situasi yang sama, yakni PJJ akibat pandemic COVID-19, namun mereka memiliki sumber stres dan sumber daya yang berbeda bahkan sebelum pandemik. Hal ini misalnya tampak pada $4(50 \%)$ partisipan yang sebelum masa pandemik sudah memiliki relasi negatif dengan orang tua, mengalami perundungan, dan riwayat sulit beradaptasi dengan lingkungan baru. Terdapat pula dua partisipan yang sebelum mengikuti intervensi memiliki ide bunuh diri dan salah satu diantaranya menjadikan self-harm sebagai usaha untuk meredakan emosi negatif setiap kali merasa tertekan dengan tuntutan keluarga maupun teman sebaya. Kondisi ini diperburuk dengan kondisi pandemi yang memaksa mereka menghadapi ketidakpastian, lebih banyak interaksi dengan orang tua, dan terbatasnya dukungan sosial dari teman sebaya (Brooks et al., 2020; Jiao et al., 2020; Rubin, 2020; Wang et al., 2020).

McLaughlin et al. (2017) menambahkan bahwa berbagai pengalaman kurang menyenangkan sebelumnya yang berisiko memicu trauma dapat mengubah perkembangan afektif dan neurobiologis individu. Kondisi inilah yang dapat pula mempengaruhi berkembangnya bias individu dalam mengidentifikasi dan memproses informasi tentang potensi ancaman di lingkungan sekaligus memicu respon emosional yang berlebihan terhadap ancaman menyerupai peristiwa traumatis. Hal ini misalnya tampak pada partisipan yang melaporkan sering merasa gagal dalam seluruh aspek hidup dan kurang berharga ketika mereka kesulitan memahami pelajaran sekolah selama PJJ karena mengasosiasikan pengalaman tersebut dengan pendisiplinan yang keras dan kurangnya penerimaan dari orang tua setiap kali mengalami kegagalan dalam memenuhi harapan orang tua sebelum pandemi. Pengalaman selama pandemi juga membangkitkan kembali ingatan kurang menyenangkan partisipan lainnya berkaitan dengan kesulitan beradaptasi 
ketika harus pindah tempat tinggal dan mengalami perundungan sebelum masa pandemi. Oleh karena itu, penelitian selanjutnya perlu mempertimbangkan kontrol pada karakteristik sumber stres partisipan sebelum intervensi untuk meminimalisir pengaruhnya terhadap hasil penelitian. Partisipan dengan sumber stres yang lebih banyak juga sebaiknya mendapatkan pendampingan lanjutan dan jika diperlukan diberikan penanganan individual untuk lebih dapat menyasar isu personal secara lebih mendalam.

Ketika follow up, sebagian partisipan juga mengeluhkan masih membutuhkan waktu untuk beradaptasi di SMA yang baru mereka jalani sekitar dua minggu. Dalam memahami fenomena ini Reid \& Kolvin (1993) menjelaskan adanya kemungkinan efek psikoterapi yang lebih lambat (sleeper effect) karena keahlian yang didapatkan individu dalam sesi intervensi kelompok baru dapat digunakan seiring bertambahnya kesempatan untuk mengaplikasikannya ketika menghadapi stres sehari-hari pada sesi follow-up. Adanya interaksi sosial yang positif di dalam sesi intervensi diikuti dengan terbangunnya interaksi sosial di luar sesi pun akan memperkuat perubahan perilaku yang positif dan penyesuaian diri yang lebih adaptif (Reid \& Kolvin, 1993; Lazarus \& Folkman, 1984). Hal yang sama dilaporkan partisipan bahwa pengalaman diterima dalam kelompok intervensi turut menumbuhkan perasaan berharga dan dipedulikan sekaligus mendorongnya menginisiasi interaksi sosial dengan teman sebayanya yang sempat berkurang semenjak PJJ akibat COVID-19. Selain itu, 2 partisipan melaporkan tidak munculnya kembali ide bunuh diri setelah dilaksanakannya intervensi. Buitron et al. (2016) juga menyebutkan bahwa intervensi yang mengembangkan perasaan terkoneksi secara sosial dan tidak menjadi beban bagi orang lain dapat menurunkan risiko keinginan bunuh diri pada remaja yang mengalami masalah interpersonal.

Pelaksanaan intervensi Online CBT secara berkelompok juga memiliki keuntungan lainnya. Kemiripan masalah yang dihadapi dan respon stres yang dialami oleh anggota kelompok, membuat partisipan menilai kondisi yang dialaminya wajar terjadi sekaligus merasa tidak sendirian menghadapi kondisi ini. Kecenderungan partisipan yang lebih membuka diri dimulai sesi ketiga juga memberikan kesempatan bagi mereka untuk mendapatkan sudut pandang baru ketika melihat suatu masalah sekaligus memberi ide cara mengatasinya dari partisipan lain. Selain itu, pengalaman berhasil partisipan lainnya ketika mengatasi situasi menekan turut memberi harapan dan meningkatkan keyakinan partisipan akan kemampuannya untuk mengatasi masalah serupa. Hal ini didukung pula keterlibatan partisipan secara bergatian sebagai pemimpin kelompok yang berperan mendorong peserta lain untuk mengerjakan tugas di rumah, ikut membantu mencairkan suasana, dan mengungkapkan pendapatnya lebih dulu di awal sesi. Umpan balik antar partisipan ketika berdiskusi dalam bentuk penerimaan, persetujuan, ataupun saling memberikan semangat baik di saat sesi kelas maupun interaksi di group messenger juga dilaporkan oleh partisipan turut mempengaruhi keterlibatan mereka di dalam kelompok sekaligus menimbulkan perasaan diterima.

Dalam hal ini, Yalom \& Leszcz (2005) menyebutkan istilah interpersonal learning-input dan output untuk menjelaskan proses belajar yang terjadi di dalam intervensi kelompok. Partisipan akan mendapatkan pemahaman tentang diri dan pengaruh dirinya dalam hubungan interpersonal lewat interaksi yang adaptif dan efektif dalam kelompok. Sejalan dengan pendapat AGPA (2007) bahwa terbangunnya therapeutic alliance dan interpersonal cohesion memungkinkan partisipan saling mengamati, meniru, dan melibatkan diri dalam perilaku positif yang ditampilkan partisipan lain dan berhubungan dengan penurunan simtom.

Di lain sisi, sama seperti penelitian Yalom \& Leszcz (2005) terdapat limitasi serupa dalam program intervensi kelompok melalui video conferencing yang dilakukan peneliti. Pertama, koneksi internet yang kurang stabil menghambat proses penyampaian materi, sesi diskusi, maupun praktik. Informasi non verbal yang bisa diperoleh dari partisipan juga terbatas ditambah masalah koneksi yang terkadang membuat mereka tidak bisa menyalakan video. Secara umum partisipan pun lebih dapat mempertahankan perhatiannya selama 60-75 menit. Hal ini mungkin dipengaruhi oleh faktor kelelahan jika terlalu lama duduk menghadap gadget. Terdapat pula beberapa partisipan yang tidak bisa hadir pada sesi intervensi karena kendala personal. Peneliti pun perlu mengadakan sesi kelas tambahan dengan 1-4 peserta, sehingga mungkin dapat mempengaruhi atmosfer yang terbangun di kelas dibandingkan ketika semua partisipan hadir (Reid \& Kolvin, 1993).

Intervensi kelompok juga tidak bisa menyesuaikan karakteristik maupun menangani kebutuhan unik individual (De Vente et al., 2008). Hal ini dibatasi oleh minimnya data yang diperoleh pada saat perekrutan daring. Kurangnya waktu di dalam sesi intervensi untuk melibatkan semua partisipan menceritakan pengalaman atau memberikan pendapatnya juga menjadi keterbatasan intervensi dalam menyasar masalah yang bersifat individual secara mendalam. Selain itu, keberadaan anggota keluarga di dalam ruangan yang sama saat sesi juga membuat perhatian partisipan mudah teralihkan sekaligus merasa kurang nyaman untuk menceritakan pengalamannya yang sebelumnya cenderung dirahasiakan dari keluarga. Oleh karena itu, pemberian psikoedukasi kepada orang tua tentang hasil intervensi termasuk bentuk keterlibatan mereka selama maupun setelah intervensi sangat diperlukan untuk bisa mengoptimalkan fungsi keseharian partisipan. Dorongan bagi remaja untuk lebih terbuka dan menjadikan orang tua ataupun orang terdekat lainnya sebagai sumber dukungan sosial pun perlu ditingkatkan apalagi jika sudah melakukan tindakan yang membahayakan diri.

Lebih lanjut, studi oleh Scheel et al. (2004) menunjukkan bahwa pengerjaan tugas di luar sesi psikoterapi termasuk pendekatan CBT merupakan indikator motivasi, 
komitmen, dan keterlibatan klien. Pemberian tugas di luar sesi juga memberikan kesempatan bagi individu untuk menerapkan keahlian yang dipelajari dalam kehidupan sehari-hari di tengah sesi dan berhubungan dengan hasil intervensi yang lebih baik dibandingkan tanpa pemberian tugas. Hal yang sama disampaikan oleh partisipan bahwa tugas membantu mereka untuk lebih mengenali diri dan mengetahui strategi coping yang dirasa paling efektif.

Di lain sisi, hanya $50 \%$ partisipan yang rutin mengumpulkan tugasnya sebelum sesi dimulai. Partisipan lainnya menyampaikan kendala perasaan malas mengerjakan ketika masih periode liburan sekolah ataupun lupa mengerjakan dan mengirimkan foto tugas. Terdapat pula 1 partisipan yang merasa kesulitan mengekspresikan pikiran, perasaan, dan perilakunya dalam bentuk tulisan, sehingga terkadang tidak menuliskannya. Dalam hal ini, sesi diskusi dan berbagi pengalaman mengerjakan tugas di rumah sebelum dimulainya sesi membantu partisipan mendapatkan pengetahuan dan sudut pandang baru tentang penerapan keahlian yang dipelajari ke dalam konteks sehari-hari. Setiap selesai sesi peneliti juga menjelaskan tujuan dari pengerjaan tugas untuk bisa menyamakan ekspektasi dan pemahaman partisipan terkait tugas. Selain itu, peneliti mencoba untuk memberikan dorongan dan umpan balik pada partisipan setiap selesai sesi maupun mengumpulkan tugas. Sejalan dengan penelitian sebelumnya bahwa pemberian dukungan, umpan balik, dan dorongan untuk melakukan selfmonitoring di antara sesi termasuk melalui pesan singkat dapat meningkatkan komitmen dan keterlibatan partisipan dalam intervensi (Kobak et al., 2015; Scheel et al., 2004). Penelitian lanjutan juga dapat mempertimbangkan pemberian pekerjaan rumah melalui daring, seperti google form dan google classroom untuk memudahkan peneliti dan peserta dalam memantau, mengumpulkan, serta mendokumentasikan tugas. Selain itu, penelitian lanjutan juga perlu mempertimbangkan adanya kelompok kontrol maupun menerapkan random assignment untuk mengatasi limitasi penelitian quasi experimental terkait kemungkinan adanya ancaman counfounding variable terhadap validitas internal (Gravetter \& Forzano, 2012)

\section{Simpulan}

Berdasarkan hasil penelitian ini, maka dapat disimpulkan bahwa intervensi Online Group CBT efektif dalam menurunkan stres yang bertahan hingga satu bulan dan meningkatkan penggunaan adaptive coping strategy terutama setelah intervensi (post-test). Meskipun tampak adanya penurunan penggunaan maladaptive coping strategy hingga 1 bulan setelah intervensi Online Group CBT, namun hasilnya ditemukan tidak signifikan. Setelah mengikuti intervensi, secara umum partisipan juga dapat mengidentifikasi dan menyadari gejala serta sumber stres yang dialami selama PJJ termasuk mengetahui dan menerapkan sejumlah strategi coping yang sehat untuk mengatasi situasi tersebut. Selain membuat partisipan merasa lebih tenang, nyaman, dan aman, teknik-teknik yang diajarkan juga mengembangkan penilaian yang positif tentang diri sendiri maupun dunia secara umum. Rata-rata partisipan juga melaporkan adanya peningkatan keyakinan akan kemampuannya mengatasi stres di kemudian hari. Meskipun demikian, sejumlah sumber stres yang masih dirasakan dan bahkan bertambah oleh partisipan ketika follow-up turut mempengaruhi dinamika penerapan coping strategy pada partisipan.

\section{Saran}

Implikasi penelitian ini bermanfaat bagi remaja perempuan, lingkungan terdekat remaja, dan penelitian selanjutnya. Remaja perempuan diharapkan mendapatkan pengetahuan tentang pentingnya menyadari gejala stres dan mengembangkan strategi self-help yang lebih adaptif ketika menghadapi situasi stres sehari-hari termasuk berkaitan dengan kegiatan belajar daring. Meskipun demikian, kesadaran dari orang tua dan pihak sekolah untuk membantu mendengarkan, menerima, dan menormalisasi kesulitan yang dialami remaja perempuan sekaligus mendorongnya untuk menerapkan strategi coping yang adaptif, termasuk meminta bantuan tenaga kesehatan mental profesional juga diperlukan untuk membantu penyesuaian diri remaja dalam kondisi pandemi COVID-19. Lebih lanjut, penelitian berikutnya diharapkan lebih mempertimbangkan karakteristik partisipan berupa sumber stres, sumber daya yang dimiliki, dan pengukuran masalah sosial emosional yang mungkin menyertai partisipan sebelum mengikuti pelatihan. Pengaruh confounding variable ini pun bisa diminimalisir dengan melibatkan kelompok kontrol dan random assignment. Pemberian pekerjaan rumah maupun debrief setiap sesi dalam bentuk formulir yang bisa diisi ataupun diunduh secara daring juga dapat menjadi pertimbangan untuk memudahkan pengerjaan maupun perekapan data penelitian yang dilakukan secara daring. Selain itu, penelitian lanjutan diperlukan untuk mengeneralisasi hasil penelitian pada partisipan dengan beragam karakteristik lainnya (seperti gender, usia, jenis sekolah, SES, dan sosial budaya).

\section{Referensi}

Allen, A. B., \& Leary, M. R. (2010). Self-Compassion, Stress, and Coping. Social and personality psychology compass, 4(2), 107-118. https://doi.org/10.1111/j.1751-9004.2009. 00246.x

American Group Psychotherapy Association (AGPA). (2007). Practice Guidelines for Group Psychotherapy. The Science to Service Task Force of American Group Psychotherapy Association.

Bitty, F., Asrifuddin, A., \& Nelwan, J. E. (2019). Stres dengan status gizi remaja di sekolah menengah pertama negeri 2 manado. Jurnal Kesmas, 7(5).

Brooks, S. K., Webster, R. K., Smith, L. E., Woodland, L., Wessely, S., Greenberg, N., \& Rubin, G. J. (2020). The 
psychological impact of quarantine and how to reduce it: rapid review of the evidence. The Lancet. https://doi.org/10. 1016/s0140-6736(20)30460-8

Buitron, V., Hill, R. M., Pettit, J. W., Green, K. L., Hatkevich, C., \& Sharp, C. (2016). Interpersonal stress and suicidal ideation in adolescence: An indirect association through perceived burdensomeness toward others. Journal of Affective Disorders, 190, 143-149. https://doi.org/10.1016/j. jad.2015.09.077

Carver, C. S. (1997). You want to measure coping but your protocol too long: Consider the brief cope. International journal of behavioral medicine, 4(1), 92-100. https://doi.org/ 10.1207/s15327558ijbm0401_6

Carver, C. S., Scheier, M. F., \& Weintraub, J. K. (1989). Assessing coping strategies: a theoretically based approach. Journal of personality and social psychology, 56(2), 267-283. https://doi.org/10.1037/0022-3514.56.2.267

Chinaveh, M. (2013). The effectiveness of multiple stress management intervention on the level of stress, and coping responses among iranian students. Procedia-Social and Behavioral Sciences, 84, 593-600. https://doi.org/10.1016/j. sbspro.2013.06.610

Cohen, S., Kamarck, T., \& Mermelstein, R.(1983). A global measure of perceived stress. Journal of Health and Social Behavior, 24, 386-396.

Cooper, C., Katona, C., \& Livingston, G. (2008). Validity and reliability of the brief COPE in carers of people with dementia: the LASER-AD Study. The Journal of nervous and mental disease, 196(11), 838-843. https://doi.org/10.1097/ NMD.0b013e31818b504c

De Anda, D. (1998). The evaluation of a stress management program for middle school adolescents. Child and Adolescent Social Work Journal, 15(1), 73-85. https://doi.org/10.1023/ A:1022297521709

De Anda, D. (2002). Student manual stress management for adolescent: A cognitive behavioral program. Research Press

De Vente, W., Kamphuis, J. H., Emmelkamp, P. M., \& Blonk, R. W. (2008). Individual and group cognitivebehavioral treatment for work-related stress complaints and sickness absence: a randomized controlled trial. Journal of occupational health psychology, 13(3), 214-231. https://doi. org/10.1037/1076-8998.13.3.214

Duan, L., \& Zhu, G. (2020). Psychological interventions for people affected by the COVID-19 epidemic. Lancet Psychiatry, 7(4), 300-302. https://doi.org/10.1016/S22150366(20)30073-0

Gravetter, F. J., \& Forzano, L. B. (2012). Research methods for behavioral sciences $4^{\text {th }} e d$. Wadsworth Cengage Learning

Hains, A. A., \& Szyjakowski, M. (1990). A cognitive stressreduction intervention program for adolescents.Journal of Counseling Psychology,37(1), 79-84. https://doi.org/10. 1037/0022-0167.37.1.79

Hofmann, S. G., Asnaani, A., Vonk, I. J. J., Sawyer, A. T., \& Fang, A. (2012). The Efficacy of Cognitive Behavioral Therapy: A Review of Meta-analyses. Cognitive Therapy and Research,
36(5), 427-440. https://doi.org/10.1007/s10608-012-9476-1

Inchausti, F., MacBeth, A., Hasson-Ohayon, I. \& Dimaggio, G. (2020). Psychological intervention and COVID-19: what we know so far and what we can do. Journal of Contemporary Psychotherapy, 50, 243-250. https://doi.org/ 10.1007/s10879-020-09460-w

Jiao, W. Y., Wang, L. N., Liu, J., Fang, S. F., Jiao, F. Y., Pettoello-Mantovani, M., \& Somekh, E. (2020). Behavioral and Emotional Disorders in Children during the COVID19 Epidemic. The Journal of Pediatrics, 221, 264-266. doi: https://doi.org/10.1016/j.jpeds.2020.03.013.

Kementerian Kesehatan Republik Indonesia (2020). Situasi terkini perkembangan coronavirus disease (COVID19) 30 Mei 2020. Infeksi Emerging: Media Informasi Terkini Penyakit Infeksi Emerging. Diunduh dari https://covid19.kemkes.go.id/situasi-infeksi-emerging/infocorona-virus/situasi-terkini-perkembangan-coronavirusdisease-covid-19-30-mei-2020/\#.X5afBm4zbMx

Keypour, M., Arman, S., \& Maracy, M. R. (2011). The effectiveness of cognitive behavioral stress management training on mental health, social interaction and family function in adolescents of families with one Human Immunodeficiency Virus (HIV) positive member. Journal of Research in Medical Sciences, 16(6), 741-749.

Kobak, K. A., Mundt, J. C., \& Kennard, B. (2015). Integrating technology into cognitive behavior therapy for adolescent depression: a pilot study. Annals of General Psychiatry, 14(37), 1-10. https://doi.org/10.1186/s12991-015-0077-8

Lazarus, R. S. (1990). Theory-based stress measurement. Psychological Inquiry, 1(1), 3-13. https://doi.org/10.1207/ s15327965pli0101_1

Lazarus, R. S., \& Folkman, S. (1980). An analysis of coping in a middle-aged community sample. Journal of health and social behavior, 21, 219-239. https://doi.org/10.2307/ 2136617

Lazarus, R. S., \& Folkman, S. (1984). Stress, appraisal, and coping. Springer Publishing Company

Lepore, S. J., Greenberg, M. A., Bruno, M., \& Smyth, J. M. (2002). Expressive writing and health: Self-regulation of emotion-related experience, physiology, and behavior. In S. J. Lepore \& J. M. Smyth (Eds.), The writing cure: How expressive writing promotes health and emotional well-being (p. 99-117). American Psychological Association. https:// doi.org/10.1037/10451-005

Lopez, J. D. (2014). Healthy and maladaptive coping strategies among master of social work students. Electronic Theses, Project, and Dissertations, California State University San Bernardino

Magson, N. R., Freeman, J. Y., Rapee, R. M., Richardson, C. E., Oar, E. L., \& Fardouly, J. (2021). Risk and protective factors for prospective changes in adolescent mental health during the COVID-19 pandemic. Journal of youth and adolescence, 50(1), 44-57. https://doi.org/10.1007/s10964-020-01332-9

McLaughlin, K. A., \& Lambert, H. K. (2017). Child trauma exposure and psychopathology: mechanisms of risk and resilience. Current opinion in psychology, 14, 29-34. https: 
//doi.org/10.1016/j.copsyc.2016.10.004

McNamara, S. (2004). Stress management programme for secondary school students. Taylor \& Francis e-Library

Östberg, V., Almquist, Y.B., Folkesson, L. et al. The Complexity of Stress in Mid-Adolescent Girls and Boys. Child Ind Res 8 , 403-423 (2015). https://doi.org/10.1007/s12187-014-92457

Pascoe, M. C., Hetrick, S. E., \& Parker, A. G. (2020). The impact of stress on students in secondary school and higher education. International Journal of Adolescence and Youth, 25(1), 104-112. https://doi.org/10.1080/02673843. 2019.1596823

Powers, J. P., Moshontz, H., \& Hoyle, R. H. (2020). Self-control and affect regulation styles predict anxiety longitudinally in university students. Collabra: Psychology, 6(1), 11-24. https://doi.org/10.1525/collabra.280

Pretzer, J. L., \& Beck, A. T. (2007). Cognitive approaches to stress and stress management. In P. L. Lehrer, R. L. Woolfolk, W. E. Sime (Ed). Principles and practice of stress management. The Guilford Press.

Raheel, H. (2014). Coping strategies for stress used by adolescent girls in Riyadh, Kingdom of Saudi Arabia. Pakistan journal of medical sciences, 30(5), 958-962. https://doi.org/10. 12669/pjms.305.5014

Rapee, R. M., Oar, E. L., Johnco, C. J., Forbes, M. K., Fardouly, J., Magson, N. R., \& Richardson, C. E. (2019). Adolescent development and risk for the onset of social-emotional disorders: A review and conceptual model. Behaviour Research and Therapy, 123, 1-14. https://doi.org/10.1016/j. brat.2019.103501

Reid, S., \& Kolvin, I. (1993). Group psychotherapy for children and adolescents. Archives of disease in childhood, 69(2), 244-250. https://doi.org/10.1136/adc.69.2.244

Rubin, G. J. (2020). The psychological impact of quarantine and how to reduce it: rapid review of the evidence. Lancet, 395(10227), 912-920. https://doi.org/10. 1016/S0140-6736(20)30460-8

Sansom-Daly, U. M., Wakefield, C. E., Bryant, R. A., Patterson, P., Anazodo, A., Butow, P., ... \& Recapture Life Working Party. (2018). Feasibility, acceptability, and safety of the Recapture Life video conferencing intervention for adoles- cent and young adult cancer survivors. Psycho-oncology, 28(2), 284-292. https://doi.org/10.1002/pon.4938

Santos-Ruiz, A., Robles-Ortega, H., Pérez-García, M., \& PeraltaRamírez, M. I. (2017). Effects of the cognitive-behavioral therapy for stress management on executive function components. The Spanish Journal of Psychology, 20(e11), 19. http://dx.doi.org/10.1017/sjp.2017.10

Sarafino, E. P. \& Smith, T. W. (2011). Health Psychology. Biopsychosocial Interaction (7th ed.). USA : Joh Wiley \& Sons, Inc.

Scheel, M. J., Hanson, W. E., \& Razzhavaikina, T. I. (2004). The process of recommending homework in psychotherapy: A review of therapist delivery methods, client acceptability, and factors that affect compliance. Psychotherapy: Theory, Research, Practice, Training, 41(1), 38-55. https://doi.org/ 10.1037/0033-3204.41.1.38

Turangga, D. (2016). Hubungan antara dorongan memaafkan dan coping dalam hubungan pertemanan pada remaja [Unpublished bachelor's thesis], Universitas Indonesia.

Wang, G., Zhang, Y., Zhao, J., Zhang, J., \& Jiang, F. (2020). Mitigate the effects of home confinement on children during the COVID-19 outbreak. The Lancet, 395(10228), 945-947. https://doi.org/10.1016/S0140-6736(20)30547-X

Wilhsson, M., Svedberg, P., Högdin, S., \& Nygren, J. M. (2017). Strategies of adolescent girls and boys for coping with school-related stress. The Journal of School Nursing, 33(5), 374-382. https://doi.org/10.1177/1059840516676875

World Health Organization (WHO) (2020, April). Archived: WHO timeline - COVID-19. Diunduh dari https://www. who. int/news/item/27-04-2020-who-timeline---covid-19

Yap, M. B. H., Reavley, N., Mackinnon, A. J., \& Jorm, A. F. (2013). Psychiatric labels and other influences on young people's stigmatizing attitudes: Findings from an Australian national survey. Journal of Affective Disorders, 148(2-3), 299-309. https://doi.org/10.1016/j.jad.2012.12.015

Yahav, R., \& Cohen, M. (2008). Evaluation of a cognitivebehavioral intervention for adolescents. International Journal of Stress Management, 15(2), 173-188. https://doi.org/10. 1037/1072-5245.15.2.173

Yalom, I. \& Leszcz, M. (2005). The Theory and practice of group psychotherapy (5th ed). Basic Books. 